\title{
RELIABILITY OF A COLLECTIVE WASTEWATER TREATMENT PLANT
}

\author{
Piotr Bugajski' , Krzysztof Chmielowski' , Grzegorz Kaczor ${ }^{1}$ \\ 1 Department of Sanitary Engineering and Water Management, Faculty of Environmental Engineering and \\ Land Surveying, H. Kołłątaja University of Agriculture in Kraków, Al. Mickiewicza 24/28, 30-059 Kraków, \\ Poland, e-mail: p.bugajski@ur.krakow.pl
}

Received: 2016.05 .13

Accepted: 2016.08.07

Published: 2016.09 .30

\begin{abstract}
The paper discusses technological reliability of a collective wastewater treatment plant (WTP). The WTP capacity expressed as population equivalents (PE) was 22,500. The research was conducted in 2013 and 2014 and it involved the collection and physical and chemical analysis of 101 samples of raw and treated sewage. Reliability analysis was based on Weibull reliability theory. Reliability of retaining organic compounds defined as $\mathrm{BOD}_{5}$ was $68 \%$, and for biogenic compounds, such as total nitrogen and total phosphorus, it was $92 \%$ and $88 \%$, respectively.
\end{abstract}

Keywords: sewage, wastewater treatment plant, technological reliability, Weibull theory

\section{INTRODUCTION}

According to the binding Regulation of the Minister of Environment as of 18 November [J. of Laws as of 16 December 2014], accuracy of wastewater treatment plant operation is based on determination of pollution concentrations in treated sewage that is then compared with acceptable concentrations set out in this Regulation. The Regulation provides also a number of samples in which the limit values may be exceeded without negatively affecting the facility performance. Therefore, if pollution concentrations for a specific number of samples are known, unequivocal conclusions on the reliability of a wastewater treatment plant may be drawn. However, a WTP operator also needs to know technological reliability of a facility, that is its capacity for proper treatment of specific amounts of sewage [Mucha and Mikosz 2009, Krzanowski and Wałęga 2006, Andraka 1997a, Andraka 1997b]. This is particularly important in the WTPs that do not monitor the quality of the sewage discharged into a receiver on a regular basis [Kuśnierz and Zarzycka 2014], i.e. in a majority of small and medium WTPs located in the rural areas of Poland. This lack of continuous monitoring is caused by reducing the operating costs of sewerage systems [Skoczko 2012]. In these WTPs, the quality of both supplied and discharged sewage is not regularly monitored and this is why the operators do not have enough information on the sewage quality. This study discusses the possibility of using Weibull reliability method for determination of wastewater treatment plant operational reliability. As showed in previous works, Weibull distribution is a useful, general probability distribution applicable in reliability assessment [Bugajski et al. 2012, Bugajski 2014].

\section{STUDY SCOPE AND OBJECTIVES}

The aim of the study was to use Weibull method to determine the reliability of organic and biogenic compound removal in a collective wastewater treatment plant. Organic pollution was defined as $\mathrm{BOD}_{5}$ and biogenic pollution was calculated based on total nitrogen and total phosphorus. The study included only those pollution indicators in the treated sewage for which limit values set out in the water permit for the facility were exceeded.

The study covered the period of two years and was conducted in a collective wastewater treat- 
ment plant in Biłgoraj. A total of 101 samples of sewage were collected and subjected to physical and chemical analyses. The efficiency of pollution removal in the facility was determined by employing some elements of Weibull reliability theory. Weibull distribution is characterized by a probability density function (1) with parameters $\mathrm{b}, \mathrm{c}$ and $\theta$ :

$$
f(x)=\frac{c}{b} \cdot\left(\frac{x-\theta}{b}\right)^{(c-1)} \cdot e^{-\left(\frac{x-\theta}{b}\right)^{c}}
$$

where: $x$-variable indicating the concentration of a specific pollution indicator in the treated sewage,

$b$ - scale parameter,

$c$ - shape parameter,

$\theta$ - location parameter.

Assumptions: $\theta<\mathrm{x}, \mathrm{b}>0, \mathrm{c}>0$

Weibull distribution parameters were estimated by means of maximum likelihood method. The applicability of Weibull distribution to the empirical data was assessed using HollanderProschan test. The results were analyzed with STATISTICA 8 software.

Mean designed daily sewage supply for the WTP in Biłgoraj was $\mathrm{Q}_{\mathrm{ms}}=8000 \mathrm{~m}^{3} \cdot \mathrm{d}^{-1}$, and maximum supply was $\mathrm{Q}_{\mathrm{dmax}}=10,000 \mathrm{~m}^{3} \cdot \mathrm{d}^{-1}$. The facility size according to the population equivalent (PE) ranged between 15,000 and 99,000 PE. Mean daily sewage supply in the study period was $4000-5000 \mathrm{~m}^{3} \cdot \mathrm{d}^{-1}$. As per the water permit issued in 2004, acceptable concentrations of the analyzed parameters in the sewage discharged into a receiver should not exceed $15 \mathrm{mgO} \cdot \mathrm{dm}^{-3}$ for $\mathrm{BOD}_{5}, 15 \mathrm{mgN} \cdot \mathrm{dm}^{-3}$ for total nitrogen and $2 \mathrm{mgP} \cdot \mathrm{dm}^{-3} \mathrm{~W}$ for total phosphorus.

\section{RESULT ANALYSIS}

The performance of the analyzed WTP was assessed in two stages. At the first stage, the frequency of specific volumes and concentrations of the analyzed parameters was determined. The analysis of the frequency of specific volumes and the concentrations are very useful statistical tools for the interpretation of data collected at irregular time intervals. Following calculations of frequency for the volume/concentration of individual indicators, the number of classes for each frequency distribution was determined. Ten classes were defined for $\mathrm{BOD}_{5}$ and the range of class interval was $5 \mathrm{mgO}_{2} \cdot \mathrm{dm}^{-3}$. For total nitrogen, there were 11 classes with the range of class interval $1 \mathrm{mgN} \cdot \mathrm{dm}^{-3}$, and for total phosphorus there were eight classes with the range of class interval $0.4 \mathrm{mgP} \cdot \mathrm{dm}^{-3}$. The class intervals were determined in such a way that the frequency distribution would yield as detailed and clear image of the statistical collection structure as possible. When the class boundaries were established, the values within individual class intervals were computed. These activities yielded a series in which each interval comprised an assigned number of observations called class abundance. The calculations were used to prepare a histogram presenting individual $\mathrm{BOD}_{5}$ values, as showed in Figure 1. Chemical analysis indicated that in 72 out of 101 samples of treated sewage $\mathrm{BOD}_{5}$ ranged from 10 to $15 \mathrm{mgO}_{2} \cdot \mathrm{dm}^{-3}$. Percentage share of $\mathrm{BOD}_{5}$ in this interval was nearly $71 \%$, as compared with all analyzed sewage samples. The study revealed nine cases of exceeding the acceptable $\mathrm{BOD}_{5}$

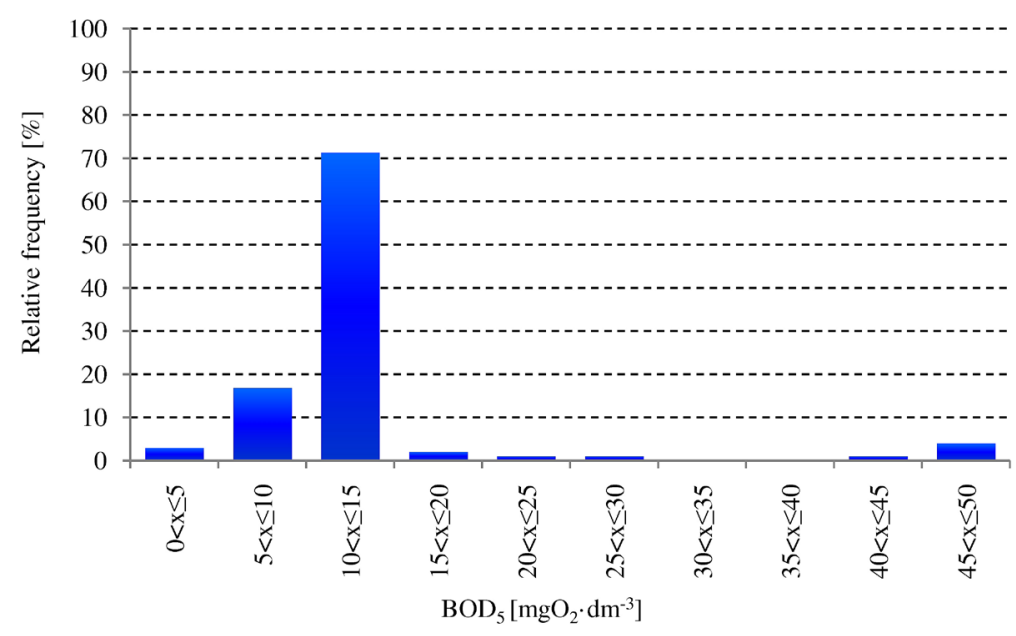

Figure 1. Histogram of characteristic $\mathrm{BOD}_{5}$ values in treated sewage 
limit that for this facility was $15 \mathrm{mgO}_{2} \cdot \mathrm{dm}^{-3}$. Total percentage share of $\mathrm{BOD}_{5}$ values exceeding the acceptable limit for all class intervals was $8.9 \%$.

Concentrations of total nitrogen in the samples of treated sewage fell into two distinct intervals, i.e. from 13 to $14 \mathrm{mgN} \cdot \mathrm{dm}^{-3}$ and from 14 to $15 \mathrm{mgN}_{\mathrm{og}} \cdot \mathrm{dm}^{-3}$. Total percentage share of total nitrogen in these intervals was $86 \%$. Acceptable concentration limit of total nitrogen was exceeded in only one sample. This is less than $1 \%$ of all samples. Characteristic concentrations of total nitrogen in individual class intervals are presented in Figure 2.

The analysis of the second eutrophication indicator, i.e. total phosphorus, revealed no dominant intervals of its characteristic concentrations in the treated sewage. Majority of concentration values (93 out of 101) fell within 0.4 to 2.0 $\mathrm{mg} \mathrm{P} \cdot \mathrm{dm}^{-3}$ range. Total percentage share of total phosphorus concentrations in these intervals was $92 \%$. In five samples, the concentration of total nitrogen was higher than the acceptable limit of $2.0 \mathrm{mg} \mathrm{P} \cdot \mathrm{dm}^{-3}$. Total percentage share of total phosphorus in 2.0 to 3.2 intervals was $4.95 \%$. Characteristic concentrations of total phosphorus in the treated sewage are presented in Figure 3.

The second stage of the study focused on reliability analysis of the investigated facility and took into account three indicators of pollution.
The determined distribution parameters were used to verify a hypothesis assuming the usefulness of Weibull distribution for the approximation of empirical data. Statistical analysis of the probability test $\mathrm{p}$ for all the indicators confirmed that the empirical data may be described by Weibull distribution and assumed as a null hypothesis. Results of distribution fit based on HollanderProschan test together with estimated parameters are presented in Table 1.

The reliability analysis based on Weibull method was used to determine the probability of occurrence of the value/concentration higher than that provided in the water permit for the facility for all three parameters.

Cumulative distribution for $\mathrm{BOD}_{5}$ showed in Figure 4 indicated that the probability of exceeding the acceptable limit of $15 \mathrm{mgO}_{2} \cdot \mathrm{dm}^{-3}$ was $42 \%$. Therefore, acceptable concentration of $\mathrm{BOD}_{5}$ in the sewage discharged into the receiver was exceeded on about 153 days per year. The guidelines prepared by Andraka and Dzienis [2003] suggested that the reliability of a wastewater treatment plant of this size should be at least $92.3 \%$, for the manufacturer's risk $\alpha=0.05$. These guidelines allow ineffective operation of a WTP with PE ranging from 15,000 to 49,999 for 27 days per year. A comparison of the number of days in which $\mathrm{BOD}_{5}$ was higher than acceptable

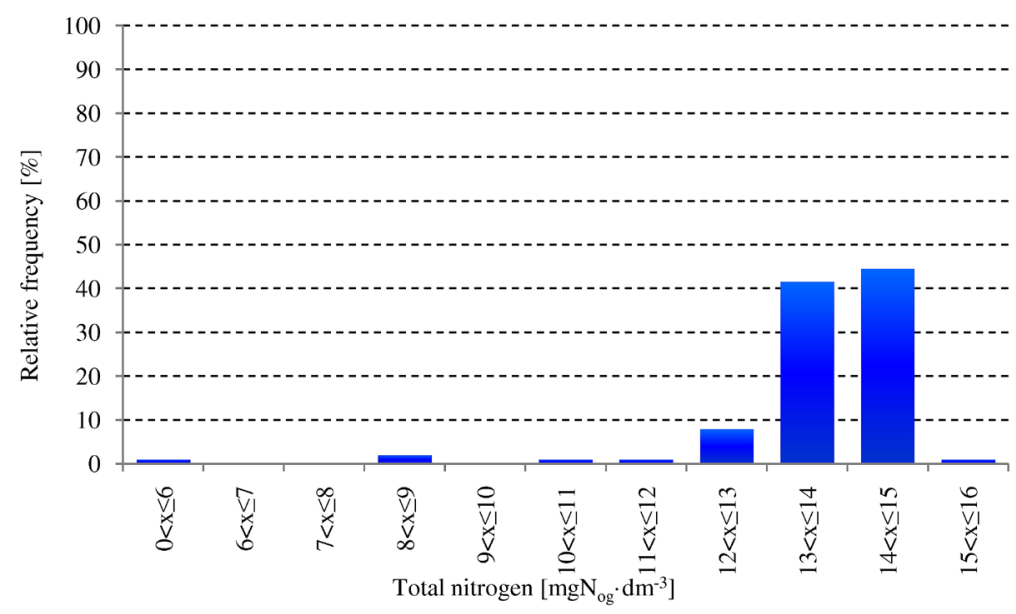

Figure 2. Histogram of characteristic concentrations of total nitrogen in treated sewage

Table 1. Results of estimation of Weibull distribution parameters with goodness of fit to empirical data

\begin{tabular}{|l|c|c|c|c|c|}
\hline \multirow{2}{*}{ Parameter } & \multicolumn{3}{c|}{ Distribution parameters } & \multicolumn{2}{c|}{ Hollander-Proschan test } \\
\cline { 2 - 6 } & $\mathrm{b}$ & $\mathrm{c}$ & $\theta$ & Test value & $\mathrm{p}$ \\
\hline $\mathrm{BOD}_{5}$ & 16.337 & 1.8815 & 4.1016 & 0.551925 & 0.58100 \\
\hline Total nitrogen & 14.230 & 17.917 & -1.000 & -1.22547 & 0.22040 \\
\hline Total phosphorus & 1.4769 & 2.4871 & 0.21515 & 0.223653 & 0.82303 \\
\hline
\end{tabular}




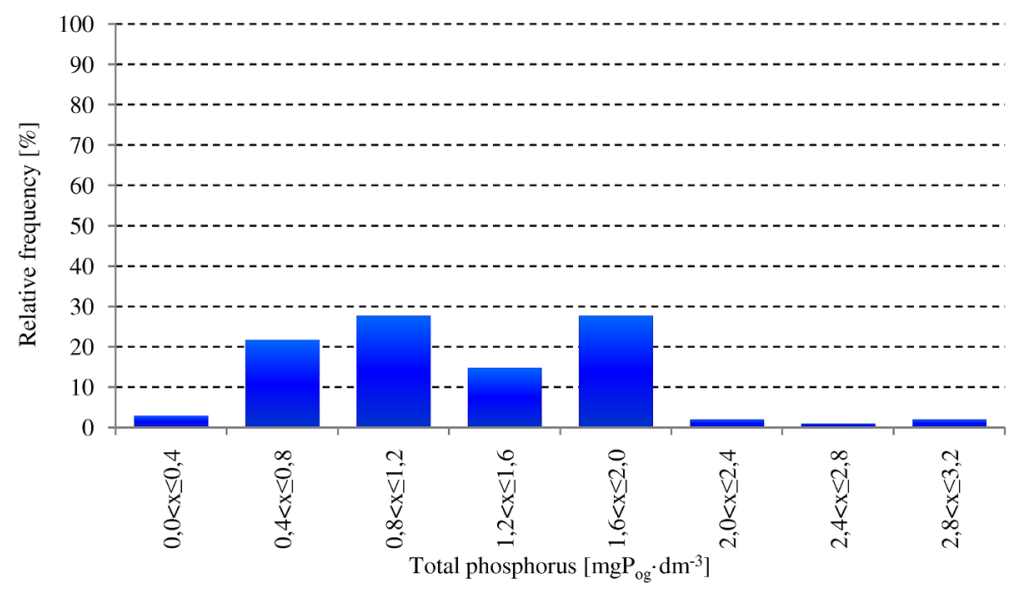

Figure 3. Histogram of characteristic concentrations of total phosphorus in treated sewage

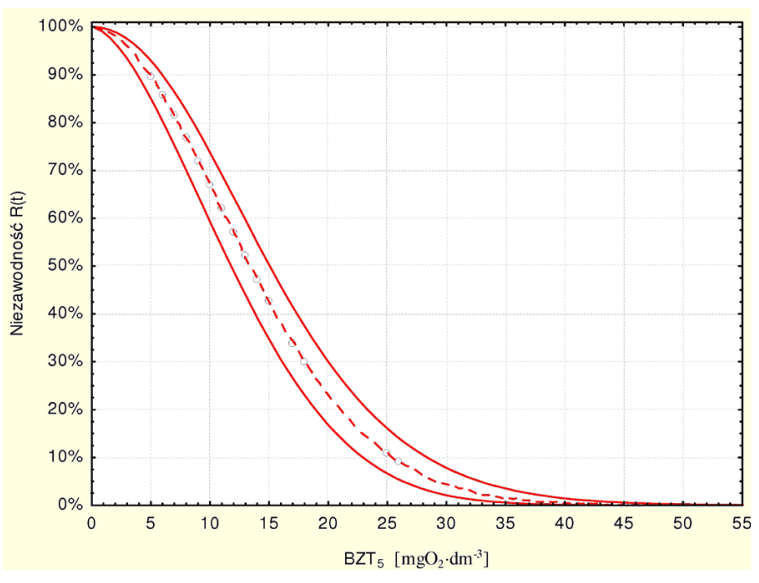

Figure 4. Results of Weibull reliability analysis for $\mathrm{BOD}_{5}$ in treated sewage

with the number of days in which exceeding this value does not affect the facility performance revealed that the normal range for $\mathrm{BOD}_{5}$ in the discharged sewage was exceeded for 126 days per year. However, significant exceedance, i.e. above $40 \mathrm{mgO}_{2} \cdot \mathrm{dm}^{-3}$ was noticed in only $5 \%$ of all cases. When only those significant excesses were considered, Weibull reliability theory showed that the efficiency of the facility was as high as $90 \%$.

Reliability analysis of total nitrogen removal revealed the probability of its concentration exceeding the acceptable limit was about $8 \%$. Therefore, nitrogen concentrations higher than the acceptable $15 \mathrm{mgN} \cdot \mathrm{dm}^{-3}$ could be expected on 29 days per year. This means the effectiveness of removing nitrogen compounds in this facility, defined here as total nitrogen, was $92 \%$. The results of Weibull reliability method for total nitrogen in the treated sewage are presented in Figure 5.

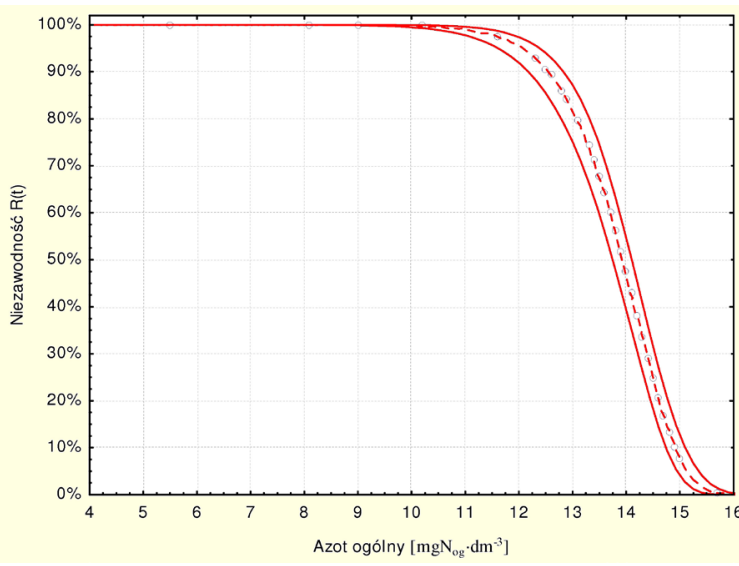

Figure 5. Results of Weibull reliability analysis for total nitrogen in treated sewage

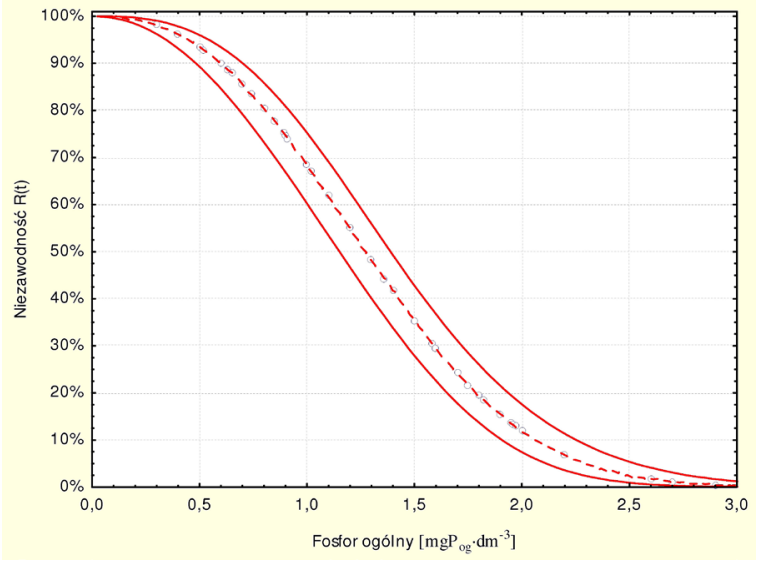

Figure 6. Results of Weibull reliability analysis for total phosphorus in treated sewage

Acceptable limits of total phosphorus $\left(2 \mathrm{mgP} \cdot \mathrm{dm}^{-3}\right)$, the second biogenic indicator, in the treated sewage were exceeded in $12 \%$ of the analyzed cases, as showed in Figure 6. Therefore, the concentration of total phosphorus was likely 
to be above the acceptable limit on 44 days per year. This means that reliability of total phosphorus removal in this facility was $88 \%$.

\section{CONCLUSIONS}

1. Reliability of the investigated wastewater treatment plant to remove organic and eutrophic pollutants defined as $\mathrm{BOD}_{5}$, total nitrogen and total phosphorus was periodically limited.

2. Reliability of retaining organic compounds defined as $\mathrm{BOD}_{5}$ was $68 \%$, and for biogenic compounds such as total nitrogen and total phosphorus it was $92 \%$ and $88 \%$, respectively.

3. Assessment of the general reliability of the facility as per Weibull reliability model demonstrated its effective operation for 239 days per year for $\mathrm{BOD}_{5}, 336$ days per year for total phosphorus and 321 days per year for total nitrogen.

4. With view of the above, the processes of nitrification and denitrification in a biological reactor of the investigated facility should be streamlined to provide more effective removal of organic and nitrogen-based compounds. Moreover, the process of chemical precipitation of phosphorus compounds should also be improved.

\section{REFERENCES}

1. Andraka D. 1997a. Ocena i prognozowanie niezawodności oczyszczalni ścieków na przykładzie oczyszczalni w Białymstoku i Grajewie. Ogólnopolska Konferencja NaukowoTechniczna nt. Bezpieczeństwo i niezawodność działania systemów gazowych, wodociągowych, kanalizacyjnych i centralnego ogrzewania, PZiTS
o/Kraków, Zakopane.

2. Andraka D. 1997b. Prognozowanie niezawodności oczyszczalni ścieków na przykładzie miejskiej oczyszczalni w Grajewie. Mat. IX Ogólnopolskiej Konferencji Naukowo-Technicznej nt. „Problemy gospodarki wodno-ściekowej w regionach rolniczoprzemysłowych", Rajgród 16-24 czerwca, 366-373.

3. Andraka D., Dzienis L. 2003. Wymagany poziom niezawodności oczyszczalni ścieków w świetle przepisów polskich i europejskich. Zesz. Nauk. Politechniki Białostockiej, Seria Inżynieria Środowiska, z. 16, Białystok, 24-28.

4. Bugajski P. 2014. Ocena niezawodności usuwania związków biogennych w oczyszczalni ścieków metodą Weibulla. Zeszyty Problemowe Postępów Nauk Rolniczych nr 276, 13-21.

5. Bugajski P., Wałęga A., Kaczor G. 2012. Zastosowanie metody Weibulla do analizy niezawodności działania przydomowej oczyszczalni ścieków. Gaz, Woda i Technika Sanitarna 2, 56-58.

6. Mucha Z., Mikosz J. 2009. Racjonalne stosowanie małych oczyszczalni ścieków z uwzględnieniem kryteriów zrównoważonego rozwoju. Czasopismo Techniczne, 2, 91-100.

7. Krzanowski S., Wałęga A. 2006. Wykorzystanie teorii niezawodności i statystycznej kontroli jakości do oceny eksploatacyjnej wiejskich oczyszczalnie ścieków. Infrastr. Ekol. Ter. Wiej., 3/2, 17-37.

8. Kuśnierz M., Zarzycka A. 2014. Zakres i częstotliwość prowadzenia badań i pomiarów w racjonalnej eksploatacji oczyszczalni ścieków. Inżynieria i Ochrona Środowiska, 17(1), 63-73.

9. Rozporządzenie Ministra Środowiska z dnia 18 listopada 2014 r. w sprawie warunków jakim powinny odpowiadać ścieki wprowadzane do wód lub do ziemi, oraz w sprawie substancji szczególnie szkodliwych dla środowiska wodnego (Dz. U. z dnia 16 grudnia 2014 r., poz. 1800).

10. Skoczko I. 2012. Ekonomiczna analiza rozwiązań oczyszczalni ścieków dla wsi przy rozproszonej zabudowie. Gaz, Woda i Technika Sanitarna nr 6, 271-275.

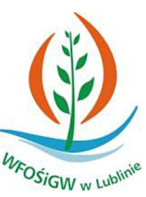

Pracę dofinansowano ze środków Wojewódzkiego Funduszu Ochrony Środowiska i Gospodarki Wodnej w Lublinie. 